\title{
Correction to: Concomitant Use of Hyaluronic Acid and Laser in Facial Rejuvenation
}

\author{
Fernando Urdiales-Gálvez ${ }^{1}$ (1) - Sandra Martín-Sánchez ${ }^{1} \cdot$ Mónica Maíz-Jiménez $^{1}$ • \\ Antonio Castellano-Miralla ${ }^{1} \cdot$ Leonardo Lionetti-Leone $^{1}$
}

Published online: 17 September 2019

(C) Springer Science+Business Media, LLC, part of Springer Nature and International Society of Aesthetic Plastic Surgery 2019

Correction to: Aesth Plast Surg (2019) 43:1061-1070
https://doi.org/10.1007/s00266-019-01393-7

The article Concomitant Use of Hyaluronic Acid and Laser in Facial written by Urdiales-Gálvez et al. was originally published electronically on the publisher's internet portal (currently SpringerLink) on May 9, 2019, without open access.

With the author(s)' decision to opt for Open Choice, the copyright of the article changed on 10/09/2019 to (C) The Author(s) 2019 and the article is forthwith distributed under the terms of the Creative Commons Attribution 4.0 International License (http://creativecommons.org/ licenses/by/4.0/), which permits use, duplication, adaptation, distribution and reproduction in any medium or format, as long as you give appropriate credit to the original author(s) and the source, provide a link to the Creative Commons license and indicate if changes were made.

The original article can be found online at https://doi.org/10.1007/ s00266-019-01393-7.

\footnotetext{
Fernando Urdiales-Gálvez

furdiales@institutomedicomiramar.com

1 Instituto Médico Miramar, Paseo de Miramar 21,

29016 Málaga, Spain
} 